\title{
Peter Szondi e o circuito
}

\author{
Peter Szondi and the circuit
}

Edelcio Mostaço

Edelcio Mostaço

Professor titular do Departamento de Artes Cênicas

e do Programa de pós-graduação em Teatro. Universidade do Estado de Santa Catarina

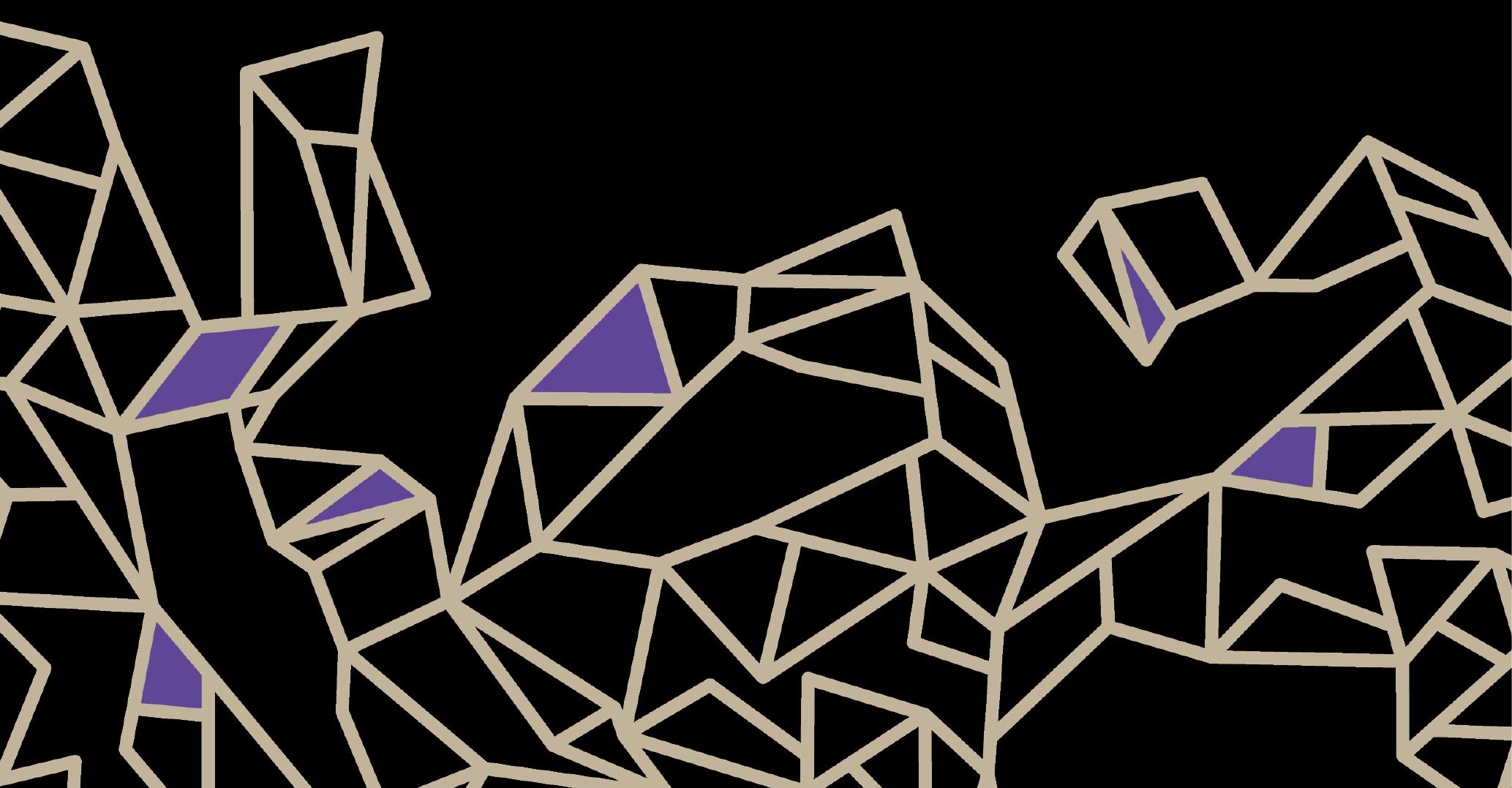




\section{Resumo}

O artigo discute a obra Teoria do drama moderno: 1880-1950, de Peter Szondi, destacando suas incongruências argumentativas e vínculos com a estética hegeliana de caráter idealista.

Palavras-chave: Peter Szondi, Drama, Idealismo, Metafísica.

\section{Abstract}

This article discusses Peter Szondi's book Theorie des modernen Dramas, emphasizing its incongruent arguments and its aesthetic bonds with Hegel's metaphysical idealism.

Keywords: Peter Szondi, Drama, Idealism, Metaphysics.

Num país como o Brasil, onde o drama não desfruta de relevância em seu universo cênico, soa incongruente a tranquila hegemonia ocupada por Teoria do drama moderno: 1880-1950, de Peter Szondi, citado em nove entre dez referências bibliográficas em circulação na academia. Quando redigido em 1956, o enfoque já estava ultrapassado no plano internacional dos estudos literários e, fora da Alemanha, permaneceu praticamente desconhecido até ser ressuscitado, já no século atual, por Jean-Pierre Sarrazac.

Aluno de Emil Staiger, que legou à filologia um título considerado clássico naqueles domínios - Conceitos fundamentais da poética -, Szondi dele partiu para organizar suas investigações, nas quais a Estética de Hegel (1997) figura como um porto seguro, além de demais luminares daquela época, seus interlocutores.

\section{Forma e conteúdo}

O projeto de Szondi (2011) se anuncia paradoxal e parte de uma proposição bastante problemática em seu intento de fundar uma "semântica das formas", pois "é essa antinomia interna que torna historicamente problemática uma forma literária e o que se adianta nas páginas seguintes é a tentativa de esclarecer as diversas formas da dramaturgia mais recente a partir da resolu- 
ção dessas contradições" (p. 20). O método empregado é o histórico-dialético, estribado nas contradições entre conteúdo e forma, problema central tomado "como contradições técnicas, ou seja, 'dificuldades' no interior da obra concreta" (loc. cit.). Logo a seguir surge a exposição do que é para o autor o drama modelar, uma súmula daquilo antes proposto por Hegel e Staiger, e definido como "absoluto", "primário", "presente" e marcado, sobretudo, pela tensão e a "relação inter-humana" Tais corolários implicam dizer que: a literatura e o drama, aqui concebidos, são pensados como fenômenos fora das contingências da língua, dos discursos e das pressões socioculturais, tomados como formas fixas ou estáveis, preservadas ao longo do tempo. Ademais, entende que o texto dramático é, enquanto matriz do fenômeno cênico, anterior e superior à cena, quando essa, em realidade, foi sua causa fundadora.

Abrindo as considerações, o autor percebe que "o homem só entrava no drama como ser que existe com outros. [...] No momento em que decidia integrar o mundo de seus contemporâneos, sua interioridade tornava-se manifesta e se convertia em presença dramática" (p. 24). Temos, portanto, uma concepção essencialista do fenômeno cênico, que toma a cena como um precipitado do mundo e dos homens reais, capaz de fazer consubstanciar suas presenças sobre o palco ou, para dizer de outro modo, acreditar que a cena é um formato de condensação dos espíritos concretos e existentes no mundo. Isso fica mais claro quando Szondi (2011), ao se referir às relações intersubjetivas que conformam o drama, usa a expressão "inter-humano" (Mitmensch, com + homem, inter-humano), importada diretamente de Hegel, termo que designa uma relação substancial, própria a seres concretos e não ficcionais, distante, portanto, da proposição original aristotélica na Poética, quando entram em cena os agentes (prattontes). Tomar a personagem como ente concreto é, inapelavelmente, recusar a ficção e seu jogo especular, articulando a cena como extensão da essência.

"O drama é uma dialética fechada em si mesma e, no entanto, uma dialética livre a ser determinada", após complementada: "o drama é absoluto. Para ser dramático, ele deve se desvencilhar de tudo o que lhe é exterior. $O$ drama não conhece nada fora de si. O dramaturgo está ausente do drama" ( $p$. 
25); o que dá a medida do estudo, que se quer anterior e externo a qualquer subjetivação estribada na experiência humana.

$\mathrm{Na}$ primeira parte da obra são analisados autores e peças enredados com o que é situado como a crise do drama, seguida por um período de transição. Na terceira, são alinhados os autores do século $X X$ que teriam desviado o drama rumo ao épico. Porque ao épico é pergunta sem resposta, já que pelo menos três dos verificados - Tchekhov, Pirandello e Miller - acusam bem mais discerníveis traços líricos que épicos.

Os gêneros narrativos nos foram legados pela Antiguidade e, no período renascentista, reciclados e reorientados pelos tradutores e comentadores da Poética aristotélica. Conheceram um revival de interesse na França neoclássica e, em seguida, voltaram ao limbo em que estiveram na maior parte do tempo até serem novamente retomados pelo lluminismo alemão. Lírico, épico e dramático, a bem da verdade, são categorias que se ajustam pouco às variadas e múltiplas narrativas possíveis e existentes, em qualquer período histórico, especialmente porque albergam uma inextrincável aderência ontológica junto à mímesis e àquelas categorias de discurso que os viram nascer nos primórdios. De modo que, desde o começo do século $\mathrm{XX}$, os estudos literários optaram por considerar os gêneros narrativos como tipologias difusas, e a admitir um quarto formato: o romanesco, dada sua indiscutível prevalência desde pelo menos dois séculos sobre o épico. Assim, duas tendências podem ser verificadas entre a crítica e os estudiosos ao longo do século XX: a indutiva, que constata a existência das formas literárias e com elas mantém uma discreta relação de referência à distância; e a dedutiva, minoritária, cujo caráter prescritivo se impõe sobre outras considerações, mesmo quando refinadas por especulações filológicas, como a de Staiger, ou filosóficas, como a de Hegel (DUCROT; TODOROV, 2001).

Desde os alvores do século $X X$, com a ampla reconsideração em relação à natureza das línguas, as funções da linguagem e o uso dos discursos, os estudos linguísticos e literários conheceram formidáveis reviravoltas, obrigando a área a se reestruturar internamente. Isso fez que - da crítica impressionista à fenomenológica, dos formalistas russos ao new criticism, da análise estruturalista à semiológica, passando por nomes ímpares como 
Bakhtin, Croce e Frye - a teoria dos gêneros fosse virada e revirada pelos estudos em dezenas de novos formatos e categorias que, ao fim e ao cabo, não apenas suplantaram as antigas proposições legadas pela tradição como as renegaram ou as substituíram por enfoques em maior consonância com as expressividades modernas e contemporâneas. De modo que, quando Szondi a retomou, já em meados do século XX, o próprio drama, quer como forma estética, quer como prática artística, há muito havia sido abandonado como marca conceitual.

Para Szondi (2011), contudo,

porque a forma de uma obra de arte tem sempre algo de inquestionável, o conhecimento de tal enunciado formal só é, em geral, alcançado por uma época em que o antes inquestionável é posto em questão e em que o naturalmente aceito passou a ser um problema. (p. 21)

Afirmativa que, sobejamente, coloca seu autor fora daquele intenso debate literário já então travado. Logo a seguir temos: "a concepção histórico-dialética de forma e conteúdo mina as bases da poética sistemática enquanto tal" (Ibid., p. 20), o que implica que a antiga prescrição poética é aceita enquanto tal, ainda que percebida como minada. Contudo, trata-se de outro tipo de empreendimento, uma vez que um novo gênero de poética teria aparecido desde o lluminismo: "trata-se da poética filosófica, que não busca regras a serem empregadas na práxis, nem diferenças a serem consideradas na escrita, mas um conhecimento que se basta a si mesmo" (SÜSSEKIND apud SZONDI, 2004, p. 16). Resumindo o palavrório: tal poética é absoluta e inquestionável, e, quando coada pela concepção histórico-dialética, ela se liquefaz gerando um conhecimento autotélico.

Tal conhecimento que se basta a si mesmo é, no rigor da letra, o projeto da metafísica. De Platão a Hegel ele é estrita theoria, a inabalável contemplação divina que recusa se sujar com a práxis dos mortais e se despreocupa com o fenomênico mundo da escritura, configurando um logos autocentrado que pensa a si para si mesmo. É o que se pode dizer dessa autocomplacente ideologia, sobre a qual cabe a arguta observação de Kant (1980, p. 69): "na metafísica é possível trabalhar-se mal de muitas maneiras, sem receio de ser colhido em erro". 
E se a diatribe ainda não foi totalmente assimilada, as palavras finais de Teoria do drama moderno: 1880-1950 não deixam qualquer dúvida:

não é algo que compete à sua teoria prescrever o que o drama moderno pode ser. [...] é tempo de simplesmente lhe conferir formulação teórica. [...] É certo que tudo o que é formal traz dentro de si, como possibilidade, sua futura tradição, [...] mas para que fosse possível um estilo novo, seria preciso não só resolver a crise do drama, mas a da própria tradição enquanto tal. (SZONDI, 2011, p. 155).

Outra golfada de raciocínios retorcidos, que ratifica a tautologia do discurso autocentrado. Se futura tradição já soa um paralogismo, é possível que o raciocínio de si para si nele vislumbre algum significado, talvez o mesmo que, supostamente, possa existir não apenas na atual crise do drama, bem como naquela crise da própria tradição enquanto tal. Ora, se a tradição já estava em crise, como sustentar propriedades essenciais como objetividade, absoluto, presente e primário como antes afirmado? E se a crise atual é a mesma que a da origem, então entre o começo e o fim só existem crises, uma sucedendo a outra.

Do ponto de vista dialético, o discurso de Szondi é pura antítese (ou negatividade, segundo a consagrada expressão cunhada por Adorno), faltando em seu cálculo tanto a tese quanto a síntese que pudessem Ihe conferir a desejável compreensibilidade ou sentido de completude enquanto significação.

\section{Texto e cena}

Mas há outra e irreversível contradição informando o estudo de Szondi (2011) - texto dramático e cena teatral são entre si confundidos: "o palco criado pelo drama do Renascimento e do Classicismo, o tão difamado 'palco como caixa de imagens', é a única forma cênica adequada ao caráter absoluto do drama" (p. 25). Assim, drama (gênero) e dramático (modo) são tomados um pelo outro, tornando indiscerníveis suas propriedades e qualidades, o que leva o autor a articular um paralelismo histórico verdadeiramente incongruente, uma vez que os dois objetos não conheceram desenvolvimentos coincidentes. O modo de produção constituído pelas técnicas expressivas (o dramático), para empregarmos o seu referencial marxista, surge deslocado 
para a superestrutura (o conceito de drama), fazendo crer que os fenômenos decorrentes e atinentes à sensibilidade corporal do espectador (ver e ouvir) sejam tomados tão somente no plano ideológico: "como que criada pela própria cena, [...] a ribalta que o ilumina procura criar a ilusão de que o espetáculo dramático sobre o palco irradia sua própria luz" (Ibid., p. 26).

Embora se pretenda rejuvenescida através da teoria crítica, tal concepção de história de Szondi é fortemente idealista, dada a confusão apontada, na qual o ilusionismo marca o termo de passagem entre uma coisa e outra, "subindo" da infra para a superestrutura, ao desligar o efeito ideológico de sua fonte de produção, problemática não mais retomada ao longo de toda a análise. A apontada "caixa de imagens" foi, ao longo do século XIX, inúmeras vezes investigada e debatida, tanto por pesquisadores das ciências, quanto por filósofos que investigaram as percepções. Em meados do século XIX, quando Szondi inicia suas conjecturas, já existiam inúmeras considerações sobre tais questões, que não mais autorizavam falar simplesmente em "mundo invertido" ou em genéricas "fantasmagorias", caracterizando o mundo mental iludido como elas surgem em A ideologia alemã, de Marx-Engels. Aos interessados no assunto, a publicação Técnicas do observador: visão e modernidade no século XIX, de Jonathan Crary (2012) oferece amplo panorama a respeito.

Embutidos nesse desacerto mais amplo, dois outros intrincados problemas permeiam os argumentos de Szondi (2011): o papel e a função da técnica na construção da obra dramatúrgica e a possível permanência (ou não) das formas no universo das obras de arte.

Ao tratar o drama como conhecendo dificuldades e, posteriormente, desvios, Szondi (2011) idealiza uma forma fixa para ele, embora sua intenção seja "apreender conceitualmente uma relação histórica objetiva" (p. 30). De acordo com ele, Ibsen é distinguido pelo emprego da técnica analítica, uma vez que seus conflitos se conformaram no passado e as criaturas os desdobram e intensificam no presente. Nessa acepção, a técnica provém do romance, uma vez que o passado só pode adentrar o drama pelo viés do relato ou da descrição. Em Tchekhov "o diálogo sem substância passa aos solilóquios substanciais", acentuando o teor lírico da escritura (Ibid., p. 43). Sobre o naturalismo de Strindberg, a observação se volta em relação à intensiva utilização do eu como foco da ação, o que descaracteriza a existência 
das demais figuras cênicas, recalcando o monólogo ou a dramaturgia do eu, que "naturalmente deixa de ser drama" (Ibid., p. 51). Se lbsen está no início da crise, Strindberg representa seu pico ao final do século, "através da inversão da épica, de tema, em forma; ambos se situam, portanto, no limiar da dramaturgia moderna" (Ibid., p. 61). Mas nem o romance, o solilóquio ou o monólogo merecem atenção maior, além da mera referência, quanto às suas características técnicas, ou seja, em que medida e de que modo eles ajudaram a materializar as estruturas épicas para as quais apontam.

Se a análise dos dramaturgos do século XIX evidencia dificuldades, a "problemática de sua forma", ela não encontrou bem-sucedida continuidade quanto aos que se seguem. A partir de Maeterlinck, e com ênfase em Schnitzler, O’Neill, Yeats, Hofmannsthal, Wedekind e Pirandello, já não se pode mais falar em drama (se pensada a totalidade da produção de cada um deles, e não exemplares isolados como faz Szondi), desmontado após as investidas futuristas, dadaístas, cubistas e expressionistas, que solaparam todo o modo dramático até então conhecido. A partir do Simbolismo, a revolução cênica do século $X X$ abertamente lutou contra as veleidades miméticas que ainda permaneciam sobre os palcos: da merde de Ubu Rei à bofetada no gosto do público de Eu, Maiakóvski, o que se conhece é uma contínua escalada do espetacular sobre o textual. Toda a dramaturgia futurista italiana pode ser sintetizada em um de seus mais notórios exemplares: "a cortina se abre. Ouve-se um tiro. A cortina se fecha" (CANGIULIO, 1921, p. 87), não apenas uma sátira feroz quanto ao drama de tese, realista e naturalista como, sobretudo, uma cena sem palavras. Não é apenas o drama que está aqui rejeitado, mas todo o modo dramático como então conhecido. $\mathrm{E}$, ainda uma vez, aquela falta de distinção szondiana entre ambos é vítima de seus raciocínios de si para si.

A revolução da vanguarda não se voltou contra um estilo ou uma espécie de arte, mas contra a própria noção de arte como cultivada pela sociedade burguesa; devolveu à atividade artística sua condição de radical heteronomia em relação à práxis social, ética e religiosa, impondo um novo território criado pelo pensamento; e sua imanência enquanto produção e não enquanto produto visou deslocar a arte para fora da mímesis e, assim, desestabilizar tudo o que até então se entendia como representação. São esses os principais argumentos de um teórico marxista que deslocou as interpretações 
evolucionistas como pertencentes a uma tradição incapaz de apreender o desenvolvimento contraditório das novas categorias abertas com o pensamento marxista - Peter Bürguer. Para ele,

a tese que Marx colocou como relevante entre o conhecimento da validade geral de uma categoria e a efetiva separação histórica dos objetos a que essa categoria se aplica vale também para as objetivações artísticas. Também aqui a diferenciação dos âmbitos dos objetos é a condição de possibilidade de um conhecimento adequado desses objetos. Mas a plena diferenciação dos fenômenos artísticos a sociedade burguesa só alcança com o esteticismo, a que respondem os movimentos de vanguarda. A tese fica mais clara com a categoria central desse meio artístico - o procedimento (BÜRGUER, 1987, p. 54).

E entre os procedimentos exemplares empregados pela vanguarda está o estranhamento - pioneiramente mobilizado por Viktor Chklóvski e, a seguir, pelos cubofuturistas e formalistas russos, construtivistas e futuristas, dadaístas e expressionistas, encontrando em Piscator e Brecht um emprego verdadeiramente político. Em acordo com o crítico russo, tal processo artístico visava singularizar a obra, obscurecendo sua forma para aumentar a dificuldade de sua assimilação e forçar, por parte do receptor, a atenção a ela dirigida, prolongando seus efeitos quanto a um devir mais intenso.

Entender esse salto operativo implica senão abandonar a dramaturgia, ao menos erguê-la em suspeição, renunciando tanto à sua função modelar enquanto drama, quanto, igualmente, enquanto modo dramático atrelado às convenções, uma vez que a renovação técnica os subverteu in totum. Bürguer grifa que o estranhamento não foi empregado em todas as produções vanguardistas, mas o destaca em função de suas características de choque, impacto igualmente verificável nas demais técnicas de vanguarda. Superar a mímesis colocou-se como um desígnio central para os artistas daquele período, efetivando assim o salto que transformou a arte de produto em produção, de objeto em fato de pensamento. Caduca, portanto, quer a dimensão de ilusionismo salvaguardada e privilegiada por Szondi, quer suas considerações efetivadas sobre a dramaturgia de O'Neill, Pirandello, Wilder ou Miller, subsumidas no viés estreito de tentativas de resolução do texto dramático. 
Quanto ao épico, foi ele apontado por Walter Benjamin (1985) como o triunfo do gesto - ou seja, do teatral - em detrimento do literário:

o teatro épico é gestual. Outra questão, bem diversa, é saber até que ponto isso ainda é poético e literário no sentido tradicional. O gesto é o seu material, enquanto a sua tarefa é a adequada valorização desse material. $O$ gesto tem duas vantagens: por um lado, frente às manifestações e assertivas verbais completamente enganosas e, por outro, frente à complexidade e intransparência das ações das pessoas. (p. 204)

Mais à frente, Benjamin destaca que o palco naturalista é inteiramente ilusionista, mimético, a maior resistência que a cena épica encontrou pela frente e contra a qual lutou com todas as forças. "O teatro épico não reproduz, portanto, situações, mas, pelo contrário, as descobre", e, apoiado pelas novas tecnologias advindas com o rádio e o cinema, "ele está à altura da evolução tecnológica" (Ibid., p. 205-206).

Mas além da derrocada interna experimentada pelo drama, as primeiras décadas do século $X X$ assistiram também a incontornável dominância do encenador quanto aos desígnios das novas expressividades cênicas, deslocando o dramaturgo para as coxias. Fato histórico da maior relevância nos domínios do dramático e que, por si só, evidencia a torção épica operada sobre os palcos: a narratividade ordenada, pensada, dirigida, é calculada agora através de um ponto de vista que a supervisiona, mesmo quando o material textual que Ihes cai nas mãos segue ainda padrões convencionais de expressividade. Seja na trilha simbolista representada por Lugné-Poe, Craig, Appia e Fuchs, seja na épica representada por Brahm, Reinhardt, Piscator e Brecht, a cena muda, e muda radicalmente. Uma crescente mecanização do palco veio permitindo, desde a última década do século XIX, inúmeras alterações, não apenas na visualidade como, sobretudo, ao criar condições para uma até então desconhecida semântica de palco. Ao lado da iluminação, esse notável aparato capaz de tornar a antiga caixa ilusionista uma luciférica máquina de produção de signos decisivamente renovados. Veio da cena, portanto, e não da dramaturgia, a revolução de procedimentos que instauraram esse novo produto dado à vista e que, somente pelos arraigados vícios de linguagem, continuava ainda a ser chamado de "dramático". 
Szondi (2011) constata, embora sem a devida relevância, os avanços da encenação ao discorrer sobre Piscator e Brecht, mas dá novo passo atrás ao admitir, em relação ao autor de Augsburg, aquilo que, mesmo em meados do século XX, ainda se evidenciava como seu maior limite enquanto dramaturgo: o emprego da fábula "como a tarefa central do teatro" (p. 120), outro modo de dizer que Brecht permanece drama (gênero) e dramático (modo). Foi a razão pela qual Hans-Thies Lehmann (2007), discípulo de Szondi, decide investigar em modo apropriado tais dessimetrias e comentar:

o processo de decomposição do drama no campo do texto, que é delineado por Szondi, corresponde ao desenvolvimento em direção a um teatro que não mais se baseia de modo algum no 'drama', seja ele (nas caracterizações da teoria do drama) aberto ou fechado, de tipo piramidal ou como um carrossel, épico ou lírico, mais centrado no caráter ou na ação. Há teatro sem drama. A questão que se opõe com o novo desenvolvimento do teatro é saber de que modo e com que consequências a ideia de teatro como representação de um cosmos fictício foi efetivamente rompida ou mesmo abandonada - um cosmos cujo encerramento foi assegurado pelo drama e pela estética teatral a ele correspondente (p. 47).

O autor de $O$ teatro pós-dramático prossegue suas considerações enfatizando que o palco já não mais comporta a conversação do antigo drama, pois não é mais "o palco que funciona como 'espaço da fala', mas o teatro em geral" (Ibid., p. 48), desvendando seu caráter anti-ilusionista, polifônico e, sobretudo, desnaturado em relação à antiga mímesis. Tanto o texto de Lehmann como exemplares artísticos paradigmáticos da nova cena então descortinada são sobejamente conhecidos, de modo que me dispenso de aqui os referir. Mas remeto, para situar tal produção, à ambígua e oscilante nomenclatura sugerida por Patrice Pavis (2010) para designá-la, produtos cênicos inconstantes e fluidos, mise-en-perf ou performise, oximoros que deambulam entre o logocentrismo e sua superação, insurgências do fantasma da mímesis ou sua radical ultrapassagem, numa cadeia de fenômenos cênicos ajuntados por Josette Féral na dilatada categoria de performativos. Ao final do século passado parecia que, efetivamente, a página do milênio fora virada e a mímesis poderia, com os salamaleques devidos às anciãs, ir para o túmulo. Mas há a França. Os franceses não renunciam facilmente às suas conquistas culturais, 
de modo que o textocentrismo por eles engendrado foi ali ressuscitado por diversas vozes, dentre elas Denis Guénoun e Jean-Pierre Sarrazac.

\section{Real e ideologia}

Guénoun (2005) efetivou, em Actions et acteurs, uma arqueologia da fábula e para tratá-la será necessário novamente escavar as origens. O teatro é, afinal, uma poética ou uma prática? Situar tal problema é voltar a Aristóteles e nele verificar a fonte de algumas confusões conceituais que se arrastaram durante séculos. Na Poética (1980, 1448a28-9) pode-se ler: "[Sófocles] se coloca ao lado de Aristófanes porque eles dois representam os prattontes [agentes] que fazem o drôntas [drama]. Vem daí, segundo alguns, o nome dramata ['poema dramático'/'drama'] porque eles imitam os homens que fazem o drôntas [dramático]".

O trecho será mais bem compreendido ao se verificar que o filósofo usara o termo "drama" também como sinônimo de tragédia em oposição à epopeia (Ibid., 1455b15), bem como também empregara o termo drama para referir a ação representada (Ibid., 1453b32). Sendo que o termo dramatikos [dramático] é igualmente empregado para designar a práxis, o modo de executar a ação, no contexto da epopeia (Ibid., 1459a19). De modo que a flutuação lexical aqui verificável não define uma especificidade para o vocábulo drama, que pode ser tanto o modo quanto o nome da ação cênica. Há uma ambiguidade de emprego entre substantivo e advérbio, coisa que, com o passar do tempo, se tornará crucial em relação à determinação da substância do fenômeno.

De maneira que Denis Guénoun (2005), ao tentar situar o que poderia ser aquele essencial "inter-humano" formulado por Hegel e Peter Szondi, atesta:

A natureza do drama reside no encadeamento, a relação causal (necessidade e verossimilhança) que se estabelece entre elas e as ações segundo a dupla série de consecução e consequência. Ora, essa ligação é de natureza lógica, e não corporal. O fio dramático, lugar de causa para um efeito, é uma linha de pensamento - não um adendo observável, visível, teatral, no sentido óptico da palavra. E um lugar lógico não recorda os eventos materiais. (p. 82) 
O mínimo que se pode concluir dessa afirmativa é que o autor leu a Poética através dos Tópicos, uma vez que a relação designada por Aristóteles diz respeito à articulação retórica, à natureza prática da ação "desempenhada pelos homens que fazem o drama"1. De fato, existem franceses mais aristotélicos que o mestre.

Nas origens, portanto, o termo drama deve ser compreendido tão somente como o resultado da ação, ou seja, da práxis, quando fica claro, nos diversos contextos em que surge, que se trata do modo da ação ser apresentada (em modo dramático) e não uma forma categorial (o drama enquanto gênero ou nome de um gênero). O que nos reenvia ao começo desse artigo, a propósito de Szondi: foram as reinterpretações de Aristóteles que promoveram a Poética à condição de texto normativo quanto à teoria de gêneros, transformando o que era uma condição ondulatória entre substantivo e advérbio numa substância lógica da forma, introduzindo a metafísica onde até então só havia física. A teoria do drama moderno encontrou, por esse viés, uma plataforma ontológica para empilhar suas teses.

Mais matizado, mais flexível, mas não menos aristotélico, Jean-Pierre Sarrazac $(2012,2013)$ tenta salvar o drama através de um projeto coletivo que agrega vários estudiosos organizados em torno da fábula, sendo que um de seus títulos o vincula diretamente a Szondi: Léxico do drama moderno e contemporâneo. No verbete drama absoluto pode-se ler:

o interesse da construção teórica do 'drama absoluto' reside nas perspectivas de análise que ela abre. [...] Elaborada em meados dos anos 1950, a teoria szondiana visava em grande parte destacar o advento das dramaturgias épicas de Piscator e Brecht como principais 'tentativas de solução' suscetíveis de responder à crise do drama. De maneira mais sutil, o conceito do drama absoluto pode apontar para uma hibridização do épico e do dramático, do individual e do coletivo, que as estéticas do século XX não cessaram de reinventar. (p. 74)

1 A relação entre verossimilhança e necessidade, a exigência de coerência encontrável na Poética, deriva da semelhança retórica entre os discursos, ao modo do silogismo, não podendo ser considerada uma condição para a ciência como nos Tópicos. Ademais, um lugar lógico que não recorda eventos materiais só pode designar, claramente, o pensamento abstrato, desligado de qualquer contágio passional, como é sempre o caso do pensamento que acorre às personagens dramáticas. 
Em outras palavras, para o projeto de Sarrazac, as vanguardas não existiram, o palco ilusionista permanece de pé e o teatro continua a ser dramático e às voltas com infindáveis tentativas de sua reinvenção. Quanto à mímesis, todavia, dada sua débil condição estiolada na sociedade do espetáculo, ele faz média, para não se desfazer da água e da criança:

podemos detectar duas direções importantes assumidas por essas formas e questionamentos no século XX: uma tende a emancipar a cena do real, ou afirmar sua autarquia, levando assim a ruptura do teatro com a mimese à sua consumação; a outra é construída sobre uma crise permanente da mimese e tenta encontrar os instrumentos de uma nova abordagem do real, infinitamente mais móvel e crítica. (SARRAZAC, 2012, p. 110).

Convocado a se decidir diante dessa bifurcação, contudo, impasse à que toda crítica não pode fugir, ele inventa um atalho que possa conduzi-lo a salvo pelo campo minado: a representação. Foi assim que os tradutores Lallot e Dupont-Roc verteram mímesis na consagrada versão francesa da Poética, justificando que imitação, a literal transcrição da palavra grega, se encontrava alquebrada pelos maus-tratos neoclássicos e carregada de efeitos negativos desde as admoestações da crítica moderna, sentidos esses que não existiam na Antiguidade. Assim, pelo excurso da representação, Sarrazac se pensa autorizado a alinhar a estratégia do desvio, a colagem, a montagem, o fragmento, o monodrama, o metadrama, a parábola, a rapsódia, o fluxo de consciência, entre outras modalidades, tão somente como cabriolés da mímesis ou do real - para ele termos sinônimos. Ele aniquila, portanto, através da preservação da fábula e repercutindo Peter Szondi - outro modo de preservar o texto ou a representação imitativa -, toda a revolução vanguardista que promoveu a autonomia da cena ao longo do século passado.

Esse jogo de refrações com o real parece não ter fim. Mesmo Freud tendo advertido a todos que o real é o mal-estar de uma ilusão, em si mesmo irrepresentável, e que o fetiche da mercadoria traz sempre embutida sua fantasmagoria, desvendada por Marx através do cálculo econômico e político, a crítica ainda insiste em fazer ouvidos moucos e olhos cegos a tudo isso que não passa de ideologia e representação. Ou theoria, para melhor 
designá-la pelo seu platônico nome de batismo e, posteriormente, como crismada por Hegel.

O teatro vive por ondas, onde artistas, críticos e nomes de protagonistas surgem e desaparecem do circuito em acordo com o fastio da plateia. Até quando durará o estrelato de Peter Szondi? Difícil saber. Estamos vivendo uma incoercível guinada regressiva em todo o mundo, o que faz a crítica cada vez mais se refugiar em ambiguidades e nos entre lugares como modo de escapar aos petardos arremessados pela produção cênica. Assim, se minha intuição não está equivocada, a próxima estrela a ocupar esse circuito épico-teórico será o abade d’Aubignac.

\section{Referências bibliográficas}

ARISTÓTELES. La Poétique: Texte, traduction, notes par Roselyne Dupont-Roc et Jean Lallot. Paris: Seuil, 1980.

BENJAMIN, W. O que é o teatro épico? In: KOTHE, F. (Org.). Walter Benjamin: Sociologia. São Paulo: Ática, 1985.

BÜRGUER, P. Teoría de la vanguardia. Barcelona: Península, 1987.

CANGIULIO, F. Detonazione. In: MARINETTI, F.T., SETTEMELI, E., CORRA, B. Teatro Futurista Sintético. Piacenza: Casa Editrice Ghelfi Costantino, 1921.

CRARY, J. Técnicas do observador: visão e modernidade no século XIX. Rio de Janeiro: Contraponto, 2012.

DUCROT, O.; TODOROV, T. Dicionário enciclopédico das ciências da linguagem. São Paulo: Perspectiva, 2001.

GUÉNOUN, D. Actions et acteurs: raisons du drame sur scène. Paris: Belin, 2005. HEGEL, G. W. F. Curso de estética: o sistema das artes. São Paulo: Martins Fontes, 1997.

KANT, I. Prolegômenos a toda metafísica futura que queira apresentar-se como ciência. In: Os pensadores. São Paulo: Abril Cultural, 1980.

LEHMANN, H.-T. O teatro pós-dramático. São Paulo: Cosac Naify, 2007.

PAVIS, P. A encenação contemporânea: origens, tendências, perspectivas. São Paulo: Perspectiva, 2010.

SARRAZAC, J.-P. Léxico do drama moderno e contemporâneo. São Paulo: Cosac Naify, 2012.

Sobre a fábula e o desvio. Rio de Janeiro: Folhetim Ensaios/7 Letras, 2013.

STAIGER, E. Conceitos fundamentais da poética. Rio de Janeiro: Tempo Brasileiro, 1977. 
SZONDI, P. Teoria do drama moderno: 1880-1950. São Paulo: Cosac Naify, 2011. SÜSSEKIND, P. Prefácio. In: SZONDI, P. Ensaio sobre o trágico. Rio de Janeiro: Zahar, 2004.

Recebido em 18/03/2016

Aprovado em 17/05/2016

Publicado em 01/07/2016 